\title{
GAMBARAN RESPON TIME PASIEN PADA MASA PANDEMI \\ COVID-19 DI INSTALASI GAWAT DARURAT (IGD) RSUD ARIFIN ACHMAD PROVINSI RIAU
}

\author{
Mahdalena ${ }^{1}$, Hellena Deli ${ }^{2}$, Erwin $^{3}$ \\ ${ }^{123}$ Fakultas Keperawatan, Universitas Riau \\ Email: lenamahdalena62@gmail.com
}

\section{Diterima: Maret 2021, Diterbitkan: Juni 2021}

\begin{abstract}
ABSTRAK
Indonesia saat ini sedang di landa wabah pandemi Covid-19 sehingga berpengaruh terhadap pasien yang datang berobat ke Instalasi Gawat Darurat/ IGD terutama dalam respon time pasien. Di masa pandemi Covid-19 respon time pasien menjadi semakin panjang, hal ini dikarenakan selama masa pandemi banyak langkah-langkah triage yang harus dilakukan. Pasien yang datang berobat ke IGD wajib dilakukan skrining Covid-19 terlebih dahulu. Tujuan penelitian ini mengetahui gambaran respon time pasien pada masa pandemi Covid-19. Penelitian ini menggunakan metode deskriptif kuantitatif. Penelitian ini dilaksanakan pada bulan Februari 2021. Sampel dalam penelitian ini sebanyak 87 orang yang dipilih dengan teknik accidental sampling. Hasil penelitian menunjukkan mayorias responden berumur 31-50 tahun sebanyak 34,5\%, berjenis kelamin laki-laki sebanyak 57,5\%, diagnosa medical (penyakit dalam) sebanyak 79,3\%, tidak pasien rujukan sebanyak 88,5\%, level kegawatan dengan Australian Tiase Scale (ATS) 3 dan Australian Tiase Scale (ATS) 4 sebanyak 44,8\%. Respon time pasien mayoritas sesuai standar sebanyak 90,8\%. Respon time pasien belum dilakukan sepenuhnya sesuai standar. Diharapkan kepada perawat IGD untuk dapat meningkatkan waktu tanggap terhadap pasien agar dapat mencegah kematian atau cacat permanen dari sebuah penyakit.
\end{abstract}

Kata kunci : Covid-19, respon time pasien

\section{ABSTRACT}

Indonesia is currently being hit by the Covid-19 pandemic outbreak, so it affects patients who come to the emergency room for treatment, especially in the patient's response time. During the Covid-19 pandemic, the patient's response time is getting longer, this is because during the pandemic there are many triage steps that must be taken. Patients who come for treatment at the ER must be screened for Covid-19 first. Purpose this study is to know the description of patient response time during the Covid-19 pandemic. This study uses a quantitative descriptive method. This research was conducted in February 2021. The sample in this study were 87 people who were selected by accidental sampling technique. The results showed that the majority of respondents aged 31-50 years were $34.5 \%$, male gender was $57.5 \%$, medical diagnosis (internal disease) was $79.3 \%$, no referral patient was $88.5 \%$, the level of emergency was with Australian Tiase Scale (ATS) 3 and Australian Tiase Scale (ATS) 4 as much as $44.8 \%$. The majority of patients' response time according to the standard was $90.8 \%$. Patient response time has not been carried out fully according to standards. It is hoped that the emergency room nurses can increase the response time to patients in order to prevent death or permanent disability from a disease.

Keywords: Covid-19, patient response time 


\section{PENDAHULUAN}

IGD merupakan salah satu unit pelayanan di rumah sakit yang memberikan pertolongan pertama dan sebagai jalan pertama masuknya pasien dengan kondisi gawat darurat. Keadaan gawat darurat adalah suatu keadaan klinis dimana pasien membutuhkan pertolongan medis yang cepat untuk menyelamatkan nyawa dan kecacatan lebih lanjut (Kemenkes RI, 2011).

Penanganan gawat darurat di Instalasi Gawat Daurat (IGD) rumah sakit mempunyai filosofinya yaitu Time Saving it's Live Saving biasa diartikan waktu adalah nyawa atau seluruh tindakan yang dilakukan pada saat kondisi gawat darurat haruslah benar-benar efektif dan efisien. Instalasi gawat darurat dikelola untuk menangani pasien gawat darurat mengancam jiwa yang melibatkan tenaga profesional terlatih serta didukung dengan peralatan khusus, sehingga perawat dalam memberikan pelayanan pasien secara cepat dan tepat. Ketepatan pelayanan di Instalasi Gawat Darurat harus didukung dengan pelaksanaan triage yang benar (Suta wijaya, 2009 dalam Surtiningsih, 2016).

Hal ini mengingatkan pada kondisi tersebut pasien dapat kehilangan nyawa hanya dalam hitungan menit saja. Berhenti nafas 2-3 menit pada manusia dapat mengakibatkan kematian yang fatal (Sutawijaya, 2009). Kebutuhan akan Respon Time (waktu tanggap) yang tepat dan efisien sangat berperan penting dalam setiap pengambilan keputusan mulai sejak awal pasien datang hingga pasien dipindahkan dari Instalasi Gawat darurat. Respon time (waktu tanggap) adalah kecepatan dalam penanganan pasien dihitung sejak pasien datang sampai dilakukan penanganan. Respon time (waktu tanggap) pelayanan dapat dihitung dengan hitungan menit dan sangat dipengaruhi oleh berbagai hal, baik mengenai jumlah tenaga maupun komponen-komponen lain yang mendukung. Ukuran keberhasilan respon time adalah selama 5 menit (Mardalena, 2016).

Menurut Keputusan Menteri Kesehatan Nomor 129 tahun 2008 mengenai Standar Pelayanan Minimal Rumah Sakit (SPM-RS), waktu tanggap pelayanan dokter di gawat darurat memiliki dimensi mutu keselamatan dan efektifitas. Kecepatan pelayanan dokter di gawat darurat adalah kecepatan pasien dilayani sejak pasien datang sampai mendapat pelayanan dokter (menit). Waktu tanggap tersebut memiliki standar maksimal 5 menit di tiap kasus. Waktu tanggap pelayanan perlu diperhitungkan agar terselenggaranya pelayanan yang cepat, responsif dan mampu menyelamatkan pasien gawat darurat (Kemenkes, 2011).

Saat sekarang ini dunia dipermasalahkan dengan wabah pandemi Covid-19. Dengan adanya wabah ini akan menambah terjadinya kasus di rumah sakit serta juga ikut mempengaruhi lamanya waktu tanggap perawat terhadap pasien karena Corona Virus Desease merupakan penyakit menular yang harus ditangani secara safety. Angka kejadian Covid-19 terus meningkat dari hari ke hari, berdasarkan data worldometers total kasus infeksi virus corona di seluruh dunia hingga 30 November 2020 telah mencapai 63.043.588 kasus. Dari jumlah itu, sebanyak 1.464.721 orang meninggal dunia, dan 43.525.291 dinyatakan sembuh. Negara yang menjadi negara dengan angka kasus tertinggi sampai saat ini adalah Amerika Serikat dengan jumlah 13.738.994 kasus, 273.032 orang 
meninggal dunia dan 8.099 .458 orang sembuh (WorldoMeter, 2020).

Di Indonesia angka kejadian Covid-19 hingga bulan Desember 2020 telah mencapai 897.000 kasus, 727.000 orang sembuh dan 25.767 orang meninggal dunia. Angga kasus tertinggi terdapat di Kota Jakarta dengan jumlah 227.000 kasus, 202.000 orang sembuh dan 3.738 orang meninggal dunia. Sedangkan di Provinsi Riau terdapat 27.371 kasus, 25.175 orang sembuh dan 636 orang meninggal dunia (WorldoMeter, 2020).

Berdasarkan survey awal yang dilakukan mengenai respon time pasien di masa pandemi Covid-19 di ruang IGD RSUD Arifin Ahmad didapatkan rata-rata respon time setiap pasien $\geq 5$ menit, hal ini dikarenakan jumlah tenaga perawat yang sedikit tidak sebanding dengan jumlah pasien yang datang ke IGD RSUD Arifin Ahmad sehingga ada beberapa pasien yang mendapatkan respon time yang lebih dari 5 menit. Sesuai dengan kondisi Indonesia saat ini yang sedang di landa wabah pandemi covid 19 membuat respon time pasien di masa pandemi Covid-19 menjadi semakin panjang, ada beberapa pasien terutama pasien dengan ATS 5 atau pasien kategori hijau mendapatkan respon time \pm 15 menit. Hal ini dikarenakan selama masa pandemi banyak langkah-langkah triage yang harus dilakukan.

Disaat pasien baru datang akan dilakukan skrining Covid-19 terlebih dahulu, pasien yang memiliki angka skrining yang $\geq 6$ akan tergolong kedalam pasien dalam pemantauan (PDP) dan akan diarahkan ke ruang IGD khusus untuk isolasi (IGD Pinere) dan tindakan selanjutnya akan diambil alih oleh perawat dan dokter di IGD Pinere, tetapi jika pasien memiliki angka skrining $<6$ maka akan dilakukan pengukuran vital sign dan di kelompokkan berdasarkan ATS. Untuk selanjutnya pasien akan di periksa oleh dokter jaga IGD serta dilakukan tindakan gawat darurat oleh perawat IGD. Selama dimasa pandemi Covid-19 lamanya respon time menjadi lebih panjang atau $>5$ menit hal ini dikarenakan semua pasien yang datang berobat ke IGD harus dilakukan skrining Covid-19. Dalam skrining Covid19 ini kita harus mengkaji secara dalam tanda gejala yang dialami pasien agar mendapatkan angka skriring yang benar. Dalam skrining inilah yang akan memperpanjang waktu respon time pasien dan disinilah perbedaan lama waktu respon time dimasa pandemi dengan sebelum pandemi, sebelum pandemi semua pasien yang berobat di IGD dapat tertangani dengan cepat karena tidak perlu dilakukan skrining, rapid test dan rongent toraks. Dalam masa pandemi sekarang ini untuk mengetahui pasien tergolong PDP (Pasien dalam pemantauan) atau bukan PDP (Pasien dalam pemantauan) dapat diketahui melalui skrining Covid-19, selain itu dilanjutkan dengan pemeriksaan rapid test dan rongent toraks. Di IGD RSUD Arifin Achmad semua pasien baik itu Pasien dalam pemantauan maupun bukan Pasien dalam pemantauan wajib dilakukan skrining Covid-19, rapid test dan rongent toraks.

Berdasarkan hasil observasi yang peneliti lakukan terhadap 15 orang pasien dengan ATS 4 atau pasien dengan warna kuning yang diambil secara acak, yaitu 5 orang pasien disaat dinas pagi, 5 orang pasien saat dinas siang dan 5 orang pasien saat dinas malam. Dari hasil observasi tersebut didapatkan respon time pasien di masa pandemi Covid-19 setiap pasien berbeda-beda. Respon time dinas pagi lebih pendek dibandingkan dengan respon time dinas sore dan malam, hal ini 
dikarenakan jumlah tenaga perawat yang bertugas di jadwal pagi lebih banyak di bandingkan dengan jadwal sore dan malam sehingga juga ikut mempengaruhi respon time pasien. Dari 5 orang pasien dijadwal dinas pagi mendapatkan respon time $\leq 5$ menit. 5 orang pasien dijadwal dinas sore diantaranya 2 orang mendapatkan respon time 5 menit dan 3 orang mendapatkan respon time $>5$ menit. 5 orang pasien dijadwal dinas malam diantaranya 1 orang mendapatkan respon time $\leq 5$ menit, 1 orang mendapatkan respon time 5 menit dan 3 orang mendapatkan respon time $>5$ menit.

Berdasarkan fenomena latar belakang di atas maka peneliti tertarik untuk meneliti "Gambaran Respon Time Pasien Pada Masa Pandemi Covid-19 di Instalasi Gawat Darurat (IGD) RSUD Arifin Achmad Provinsi Riau".

Tujuan dari penelitian ini adalah Untuk mengetahui gambaran respon time pasien pada masa pandemi Covid-19 di Instalasi Gawat Darurat (IGD) RSUD Arifin Achmad Provinsi Riau.

\section{METODE}

Penelitian ini merupakan penelitian deskriptif sederhana untuk menggambarkan respon time pasien pada masa pandemi Covid-19 di Instalasi Gawat Darurat (IGD) RSUD Arifin Achmad Provinsi Riau. Variabel yang digunakan dalam penelitian ini yaitu respon time pasien pada masa pandemi Covid-19 sebagai variabel independen.

Populasi dalam penelitian ini adalah pasien yang datang berobat ke Instalasi Gawat Darurat (IGD) RSUD Arifin Achmad Provinsi Riau dari bulan September sampai dengan November 2020 sejumlah 1.986 pasien dengan kunjungan rata-rata dalam satu bulan sejumlah 662 orang dan rata-rata kunjungan dalam satu hari sebanyak 22 pasien.
Pengambilan sampel dilakukan secara Accidental sampling dimana teknik pengambilan sampel berdasarkan kebetulan yaitu responden yang secara kebetulan atau insidental bertemu dengan peneliti dapat digunakan sebagai sampel bila dipandang responden itu cocok dijadikan sampel sampai data terpenuhi. Sampel pada penelitian ini adalah pasien yang datang berobat ke Instalasi Gawat Darurat (IGD) RSUD Arifin Achmad Provinsi Riau sebanyak 87 pasien.

Analisa dalam penelitian ini menggunakan analisis univariat yang menyajikan data dalam bentuk persentase yaitu karakteristik responden meliputi usia, jenis kelamin, diagnosa, rujukan dan level kegawatan. Pada penelitian ini juga ingin melihat respon time pasien pada masa pandemi Covid-19 berdasarkan usia, jenis kelamin, diagnosa, rujukan dan level kegawatan dengan menggunakan lembar observasi yang telah dilakukan uji etik sebelumnya.

\section{HASIL DAN PEMBAHASAN}

Tabel 1. Karakteristik pasien (umur, jenis kelamin, diagnosa, rujukan, level

\begin{tabular}{lcc}
\multicolumn{3}{c}{ kegawatan) } \\
\hline $\begin{array}{l}\text { Karakteristik } \\
\text { responden }\end{array}$ & f & $\mathbf{\%}$ \\
\hline Umur & & \\
$\quad<20$ tahun & 21 & $24,2 \%$ \\
$20-30$ tahun & 7 & $8 \%$ \\
$31-50$ tahun & 30 & $34,5 \%$ \\
$>50$ tahun & 29 & $33,3 \%$ \\
\hline Total & $\mathbf{8 7}$ & $\mathbf{1 0 0 \%}$ \\
\hline
\end{tabular}

\begin{tabular}{lll}
$\begin{array}{c}\text { Jenis kelamin } \\
\text { Laki-laki }\end{array}$ & 50 & $57,5 \%$ \\
Perempuan & 37 & $42,5 \%$ \\
\hline Total & $\mathbf{8 7}$ & $\mathbf{1 0 0 \%}$ \\
\hline
\end{tabular}

\begin{tabular}{ccc} 
Diagnosa & & \\
Surgical & 18 & $20,7 \%$ \\
Medical & 69 & $79,3 \%$ \\
\hline Total & $\mathbf{8 7}$ & $\mathbf{1 0 0 \%}$ \\
\hline & & \\
Rujukan & & \\
Tidak & 77 & $88,5 \%$ \\
Ya & 10 & $11,5 \%$ \\
\hline
\end{tabular}




\begin{tabular}{lcc} 
Total & $\mathbf{8 7}$ & $\mathbf{1 0 0 \%}$ \\
\hline Level kegawatan & & \\
ATS 1 & 2 & $2,3 \%$ \\
ATS 2 & 7 & $8 \%$ \\
ATS 3 & 39 & $44,8 \%$ \\
ATS 4 & 39 & $44,8 \%$ \\
\hline Total & $\mathbf{8 7}$ & $\mathbf{1 0 0 \%}$ \\
\hline & & \\
Respon time & & \\
Tidak sesuai & 8 & 9,2 \\
$\quad$ standar & & \\
Sesuai standar & 79 & 90,8 \\
\hline Total & $\mathbf{8 7}$ & $\mathbf{1 0 0}$ \\
\hline
\end{tabular}

Dari tabel 1 di atas dapat diketahui bahwa karakteristik responden berdasarkan umur dari 87 responden sebagian besar responden berumur 31-50 tahun sebanyak $30(34,5 \%)$. Berdasarkan jenis kelamin sebagian besar responden berjenis kelamin laki-laki sebanyak $50 \quad(57,5 \%)$. Berdasarkan diagnosa sebagian besar responden dengan diagnosa medical sebanyak 69 (79,3\%). Berdasarkan rujukan sebagian besar responden tidak pasien rujukan sebanyak 77 (88,5\%). Berdasarkan level kegawatan sebagian besar responden dengan ATS 3 dan ATS 4 sebanyak 39 (44,8\%). Sedangkan respon time pasien pada masa pandemi Covid-19 dari 87 responden sebagian besar responden mendapatkan respon time yang sesuai standar yaitu sebanyak 79 (90,8\%). Penelitian ini sejalan dengan penelitian yang dilakukan oleh Mufidah (2018) tentang hubungan respon time perawat dengan complaint handling (penanganan keluhan) dalam pelayanan keperawatan di ruang Dahlia RSUD Jombang bahwa karakteristik responden berdasarkan umur dari 45 orang responden sebagian besar responden mempunyai umur 36-45 tahun sebanyak 30 orang $(66,7 \%)$ dan berdasarkan jenis kelamin sebagian besar responden berjenis kelamin perempuan sebanyak 32 orang $(71,1 \%)$.

Sedangkan penelitian yang dilakukan oleh Mahyawati (2015) tentang hubungan kegawatdaruratan pasien dengan waktu tanggap perawat di IGD RS PKU Muhammadiyah Yogyakarta didapatkan dari 55 pasien masalah kesehatan pasien tertinggi yaitu pasien dengan gangguan imunitas (non bedah) sebanyak 22 (40,04\%) pasien, sedangkan menurut klasifikasi kegawatdaruratan pasien mayoritas pasien yang datang ke IGD yaitu pasien dengan darurat tidak gawat (ATS 3 dan 4) sebanyak $32 \quad(58,2 \%)$ pasien. Penelitian ini sejalan dengan penelitian yang peneliti lakukan. Begitu juga dengan penelitian yang dilakukan oleh Triyono (2020) tentang hubungan response time dan komunikasi dengan kepuasan keluarga pasien di Instalasi Gawat Darurat (IGD) Rumah Sakit Ortopedi Prof. Dr. R. Soeharso Surakarta, bahwa dari 92 responden sebagian besar serponden berumur 36-45 tahun sebanyak 36 orang $(39,1 \%)$ dan sebagian besar berjenis kelamin perempuan sebanyak 69 orang (75\%). Dari 92 responden sebagian besar responden mendapatkan respon time yang cepat sebanyak 54 orang $(58,7 \%)$.

Menurut asumsi peneliti perawat harus memberikan pelayanan yang cepat dan tepat kepada pasien agar pasien merasa puas, karena kepuasan pasien tergantung pada kualitas pelayanan. Kualitas pelayanan yang baik dapat ditentukan oleh baik buruknya suatu pelayanan jasa juga termasuk lamanya waktu tanggap (respon time). Respon time yang dikatakan baik dan sesuai standar adalah $\leq 5$ menit. Setiap pasien yang datang berobat ke IGD berhak untuk mendapatkan waktu tanggap yang $<5$ menit terutama pasien dengan level 
kegawatan gawat darurat atau ATS 1 dan 2 atau pasien dengan warna merah. Pada penelitian ini respon time pasien yang didapatkan sewaktu survey awal sangat berbeda dengan respon time pasien sewaktu penelitian, respon time pasien sewatu pengambilan data awal rata-rata $>$ 5 menit, hal ini dikarenakan pengambilan data awal dilakukan pada bulan Oktober 2020 dimana angka kejadian Covid-19 sangat banyak setiap pasien wajib dilakukan skrining Covid-19 secara detail tidak hanya secara garis besar saja, selain itu jumlah perawat yang bertugas di IGD sedikit karena ruang IGD di bagi menjadi IGD pinere dan IGD umum dan tenaga perawatnya juga terbagi 2, sehingga julmah perawat yang dinas pershift tidak sesuai dengan jumlah pasien yang berobat ke IGD. Pada saat penelitian respon time pasien semakin membaik dan rata-rata sesuai standar ( $<5$ menit) hal ini di karenakan angka kejadian Covid-19 sudah mulai berkurang karena penelitian dilakukan pada bulan Februari tahun 2021, skrining Covid-19 masih tetap dilakukan tetapi tidak terlalu detail dalam mengkaji pasien, mengkaji hanya secara garis besar keluhan pasien saja, selain itu di IGD umum juga sudah ada penambahan tenaga perawat, sehingga jumlah perawat yang dinas pershift sudah dapat memberikan respon time yang sesuai standar kepada pasien.

Respon time dapat dipengaruhi oleh banyak faktor seperti jumlah tenaga perawat pada saat shift dinas, masa kerja perawat, sarana dan prasarana, dan level kegawatan. Dalam penelitian ini level kegawatan pasien berdasarkan Australian Tiase Scale (ATS) yaitu ATS 1 sampai ATS 5.
Tabel 2. Respon time berdasarkan umur

\begin{tabular}{lcccccc} 
& \multicolumn{3}{c}{ Respon time } & \multicolumn{1}{c}{ Total } \\
\cline { 2 - 5 } Umur & $\begin{array}{c}\text { Tidak } \\
\text { sesuai } \\
\text { standar }\end{array}$ & $\begin{array}{c}\text { Sesuai } \\
\text { standar }\end{array}$ & & & \\
\cline { 2 - 6 } & $\mathbf{n}$ & $\mathbf{\%}$ & $\mathbf{n}$ & $\mathbf{\%}$ & $\mathbf{n}$ & $\mathbf{\%}$ \\
\hline$<\mathbf{2 0}$ th & 4 & 19 & 17 & 81 & 21 & 100 \\
$\mathbf{2 0 - 3 0}$ th & 0 & 0 & 7 & 100 & 7 & 100 \\
$\mathbf{3 1 - 5 0}$ th & 0 & 0 & 30 & 100 & 30 & 100 \\
$>\mathbf{5 0}$ th & 4 & 13,8 & 25 & 86,2 & 29 & 100 \\
Total & $\mathbf{8}$ & $\mathbf{9 , 2}$ & $\mathbf{7 9}$ & $\mathbf{9 0 , 8}$ & $\mathbf{8 7}$ & $\mathbf{1 0 0}$ \\
\hline
\end{tabular}

Hasil analisis tabel 2 tentang gambaran respon time pasien pada masa pandemi Covid-19 berdasarkan umur dari 87 responden ada 30 responden berumur $31-50$ tahun terdapat $30(100 \%)$ dengan respon time yang sesuai standar.

Penelitian ini sejalan dengan penelitian yang dilakukan oleh Jaya (2017) tentang hubungan respon time dengan kepuasan pasien di IGD RS tingkat IV Madiun didapatkan bahwa dari 63 responden rata-rata responden berusia 36 tahun dengan usia termuda 26 tahun dan usia tertua 50 tahun. Respon time dalam penelitian ini sebagian besar pasien mendapatkan respon time yang baik sebanyak 39 responden (61,9\%). Sedangkan penelitian yang dilakukan oleh Virgo (2018) tentang hubungan response time pelayanan Instalasi Gawat Darurat (IGD) dengan tingkat kepuasan pasien di RSUD Bangkinang didapatkan bahwa dari 80 responden sebagian besar responden berumur 46-55 tahun sebanyak 42 orang (52,5\%). Respon time dalam penelitian ini sebagian besar pasien mendapatkan respon time yang lambat sebanyak 51 orang $(63,8 \%)$. Penelitian ini tidak sejalan dengan penelitian yang peneliti lakukan. 
Menurut asumsi peneliti jenis

Menurut asumsi peneliti pasien yang mendapatkan respon time yang tidak sesuai standar adalah pasien yang berumur $<20$ tahun dan $>50$ tahun, hal ini dikarenakan kita wajib melakukan skrining Covid-19 kepada pasien yang datang ke IGD, dan di dukung juga karena pasien tersebut tidak termasuk pasien yang gawat dan darurat, selain itu banyaknya pasien yang datang pada shift tersebut juga mempengaruhi lamanya respon time pasien jadi tenaga kesehatan lebih mengutamakan penanganan terhadap pasien yang gawat dan darurat.

\section{Tabel 3. Respon time berdasarkan jenis} kelamin

\begin{tabular}{lcccccc}
\hline \multirow{4}{*}{$\begin{array}{c}\text { Jenis } \\
\text { kelamin }\end{array}$} & $\begin{array}{c}\text { Tidak } \\
\text { sesuai } \\
\text { standar }\end{array}$ & $\begin{array}{c}\text { Sesuai } \\
\text { standar }\end{array}$ & \multirow{2}{*}{ Total } \\
\cline { 2 - 6 } & $\mathbf{n}$ & $\mathbf{\%}$ & $\mathbf{n}$ & $\mathbf{\%}$ & $\mathbf{n}$ & $\mathbf{\%}$ \\
\hline Laki-laki & 4 & 8 & 46 & 92 & 50 & 100 \\
Perempuan & 4 & 10,8 & 33 & 89,2 & 37 & 100 \\
Total & $\mathbf{8}$ & $\mathbf{9 , 2}$ & $\mathbf{7 9}$ & $\mathbf{9 0 , 8}$ & $\mathbf{8 7}$ & $\mathbf{1 0 0}$ \\
\hline
\end{tabular}

Hasil analisis tabel 3 tentang gambaran respon time pasien pada masa pandemi Covid-19 berdasarkan jenis kelamin dari 87 responden ada 50 responden berjenis kelamin laki-laki terdapat 46 (92\%) dengan respon time yang sesuai standar. Penelitian ini sejalan dengan penelitian yang dilakukan oleh Jaya (2017) tentang hubungan respon time dengan kepuasan pasien di IGD RS tingkat IV Madiun didapatkan bahwa dari 63 responden sebagian besar responden berjenis kelamin perempuan sebanyak 33 orang (52,4\%). Respon time dalam penelitian ini sebagian besar pasien mendapatkan respon time yang baik sebanyak 39 responden $(61,9 \%)$. kelamin tidak mempengaruhi lama atau lambatnya respon time, dalam penelitian ini ada ditemukan ada 4 orang laki-laki dan 4 orang perempuan yang mendapatkan respon time yang tidak sesuai standar, hal ini bukanlah dipengaruhi oleh faktor jenis kelamin, melainkan ada faktor lain yang sangat berpengaruh terhadap respon time yang tidak sesuai standar seperti lamanya waktu yang di butuhkan untuk skrining Covid-19 karena ada pasien atau keluarga yang tidak menjawab dengan jujur mengenai pertanyaan yang diajukan. Sehingga membuat perawat lebih mengkaji lebih dalam lagi, selain itu dapat dipengaruhi juga dengan banyaknya pasien yang datang pada saat shift tersebut atau sedikitnya perawat yang dinas di shift tersebut sehingga jumlah pasien yang datang tidak sebanding dengan jumlah perawat yang dinas.

Tabel 4. Respon time berdasarkan diagnosa

\begin{tabular}{lcccccc}
\hline \multirow{4}{*}{$\begin{array}{l}\text { Diag } \\
\text { nosa }\end{array}$} & $\begin{array}{c}\text { Tidak } \\
\text { sesuai } \\
\text { standar }\end{array}$ & $\begin{array}{c}\text { Sesuai } \\
\text { standar }\end{array}$ & & & Total \\
& $\mathbf{n}$ & $\mathbf{\%}$ & $\mathbf{n}$ & $\mathbf{\%}$ & $\mathbf{n}$ & $\mathbf{\%}$ \\
\hline Surgical & 6 & 33,3 & 12 & 66,7 & 18 & 100 \\
Medical & 2 & 2,9 & 67 & 97,1 & 69 & 100 \\
Total & $\mathbf{8}$ & $\mathbf{9 , 2}$ & $\mathbf{7 9}$ & $\mathbf{9 0 , 8}$ & $\mathbf{8 7}$ & $\mathbf{1 0 0}$ \\
\hline
\end{tabular}

Hasil analisis tabel 4 tentang gambaran respon time pasien pada masa pandemi Covid-19 berdasarkan diagnosa dari 87 responden ada 69 responden dengan diagnosa medical terdapat 67 $(97,1 \%)$ dengan respon time yang sesuai standar. Penelitian ini sejalan dengan penelitian yang dilakukan oleh Sabriyati, dkk (2012) tentang faktor-faktor yang berhubungan dengan ketepatan waktu tanggap penanganan kasus pada respon 
time di instalasi gawat darurat bedah dan non bedah RSUP DR. Wahidin Sudirohusodo didapatkan waktu tanggap penanganan kasus IGD bedah yang tepat sebanyak $67,9 \%$ dan tidak tepat $32,1 \%$. Sedangkan waktu tanggap penanganan kasus di IGD Non-Bedah yang tepat sebanyak $82,1 \%$ dan tidak tepat $17,9 \%$.

Sedangkan penelitian yang dilakukan oleh Handayani (2017) tentang hubungan waktu tanggap (respon time) perawat dengan ketepatan penanganan trauma di IGD RSUD Ulin Banjarmasin didapatkan bahwa dari 41 pasien ada 39 pasien trauma mendapatkan respon time yang cepat terdapat $39(97,5 \%)$ dengan penanganan trauma yang tepat. Penelitian ini sejalan dengan penelitian yang peneliti lakukan.

Menurut asumsi peneliti respon time dapat dipengaruhi oleh diagnosa pasien, pasien dengan diagnosa klinis surgical (bedah) harus mendapatkan respon time yang sesuai standar karena pasien dengan trauma, perdarahan harus cepat ditangani agar tidak terjadi akibat yang fatal seperti syok hipovolemik, akan tetapi dalam penelitian ini ada ditemukan pasien dengan diagnosa bedah mendapatkan respon time yang tidak sesuai standar karena pasien tersebut mengalami diagnosa klinis bedah tetapi tidak dengan perdarahan yang aktif sehingga termasuk pasien dengan kasus darurat dan tidak gawat. Sedangkan pasien dengan diagnosa klinis medical (penyakit dalam/non bedah) mayoritas juga mendapatkan respon time yang sesuai standar, ini menandakan kualitas pelayanan yang diberikan kepada pasien sudah termasuk maksimal, akan tetapi masih ada $2,9 \%$ pasien yang mendapatkan respon time yang tidak sesuai standar dikarenakan pasien tersebut merupakan kasus yang tidak gawat dan tidak darurat seperti pasien dengan diagnosa kanker yang akan melakukan kemoterapi di ruang rawat inap, pasien dengan nyeri perut (colic abdomen).

Tabel 5. Respon time berdasarkan rujukan

\begin{tabular}{lcccccc}
\hline & \multicolumn{3}{c}{ Respon time } & & \\
\cline { 2 - 5 } $\begin{array}{c}\text { Ruju- } \\
\text { kan }\end{array}$ & $\begin{array}{c}\text { Tidak } \\
\text { sesuai } \\
\text { standar }\end{array}$ & $\begin{array}{c}\text { Sesuai } \\
\text { standar }\end{array}$ & & Total \\
& $\mathbf{n}$ & $\mathbf{\%}$ & $\mathbf{n}$ & $\mathbf{\%}$ & $\mathbf{n}$ & $\mathbf{\%}$ \\
\hline Tidak & 6 & 7,8 & 71 & 92,2 & 77 & 100 \\
Ya & 2 & 20 & 8 & 80 & 10 & 100 \\
Total & $\mathbf{8}$ & $\mathbf{9 , 2}$ & $\mathbf{7 9}$ & $\mathbf{9 0 , 8}$ & $\mathbf{8 7}$ & $\mathbf{1 0 0}$ \\
\hline
\end{tabular}

Hasil analisis tabel 5 tentang gambaran respon time pasien pada masa pandemi Covid-19 berdasarkan rujukan dari 87 responden ada 77 responden yang tidak pasien rujukan terdapat $71(92,2 \%)$ dengan respon time yang sesuai standar. Menurut asumsi peneliti pasien dengan rujukan atau tidak rujukan dapat mempengaruhi lamanya respon time karena setiap pasien yang datang ke IGD kita harus memprioritaskan pasien berdasarkan level kegawatannya selain itu pada saat sekarang ini adalah masa pendemi Covid-19 pasien wajib dilakukan skrining terlebih daluhu.

Pasien yang datang sendiri ke IGD tentu dilakukan skrining terlebih dahulu oleh perawat dan pada saat skrining inilah yang membutuhkan waktu lebih lama. Sedangkan pasien yang datang dengan rujukan cendrung mendapatkan watu respon time yang sesuai standar karena pada saat pasien datang kita sudah dapat mengisi skrining sesuai dengan surat rujukan yang diajukan karena setiap pasien yang akan di rujuk wajib melaporkan keluhan, diagnosa, hasil skrining, dan hasil pemeriksaannya yang telah dilakukan di 
rumah sakit yang merujuk sebelum pasiennya di bawa ke IGD RSUD Arifin Achmad. Pada penelitian ini masih ada ditemukan $20 \%$ pasien dengan rujukan yang mendapatkan respon time yang tidak sesuai standar karena fasilitas kesehatan yang merujuk pasien adalah dari Puskesmas yang belum tau tentang prosedur rujukan pada masa pandemi Covid-19, seperti FasKes yang merujuk tidak mengkonfirmasi atau tidak menghubungi via telepon terlebih dahulu sehingga pasien yang dirujuk tersebut harus di lakukan skrining ulang dan dilanjutkan dengan primery survey. Seain itu juga didukung dengan pasien yang dirujuk bukanlah pasien dengan kasus gawat darurat melainkan pasien dnegan kasus darurat tidak gawat yang membutuhkan pemeriksaan lebih lanjut seperti rongent, CT-Scan atau membutuhkan penanganan lebih lanjut dengan dokter spesialis tertentu.

Tabel 6. Respon time berdasarkan level kegawatan

\begin{tabular}{ccccccc}
\hline \multirow{2}{*}{$\begin{array}{c}\text { Level } \\
\text { kegawa- } \\
\text { tan }\end{array}$} & $\begin{array}{c}\text { Tidak } \\
\text { sesuai } \\
\text { standar }\end{array}$ & $\begin{array}{c}\text { Sesuai } \\
\text { standar }\end{array}$ & \multirow{2}{*}{ Total } \\
\cline { 2 - 5 } & $\mathbf{n}$ & $\mathbf{\%}$ & $\mathbf{n}$ & $\mathbf{\%}$ & $\mathbf{n}$ & $\mathbf{\%}$ \\
\hline ATS 1 & 0 & 0 & 2 & 100 & 2 & 100 \\
ATS 2 & 0 & 0 & 7 & 100 & 7 & 100 \\
ATS 3 & 6 & 15,4 & 33 & 84,6 & 39 & 100 \\
ATS 4 & 2 & 5,1 & 37 & 94,9 & 39 & 100 \\
Total & $\mathbf{8}$ & $\mathbf{9 , 2}$ & $\mathbf{7 9}$ & $\mathbf{9 0 , 8}$ & $\mathbf{8 7}$ & $\mathbf{1 0 0}$ \\
\hline
\end{tabular}

Hasil analisis tabel 6 tentang gambaran respon time pasien pada masa pandemi Covid-19 berdasarkan level kegawatan dari 87 responden ada 39 responden dengan Australian Tiase Scale (ATS) 4 terdapat 37 (94,9\%) dengan respon time yang sesuai standar.

Respon time sangat berhubungan dengan triage dimana standar triage yang paling banyak digunakan di Rumah Sakit untuk penanganan pasien di negara Australia dengan menggunakan lima kategori diantaranya, sangat mengancam hidup maka waktu tanggapnya langsung ( 0 menit), sedikit mengancam hidup (10 menit), beresiko mengancam hidup (30 menit), darurat (60 menit) dan kategori biasa dengan waktu perawatan (120 menit). Di negara Kanada juga terdapat lima tingkatan triage yaitu Resusitasi ( 0 menit), gawat darurat (0 menit), darurat ( $<30$ menit), tingkat biasa ( $<60$ menit) dan tidak gawat $(<120$ menit) (Departemen Of Health and Ageing Of Australian Government dalam Kartikawati, 2013). Menurut penelitian yang dilakukan oleh Mahyawati (2015) tentang hubungan kegawatdaruratan pasien dengan waktu tanggap perawat di IGD RS PKU Muhammadiyah Yogyakarta didapatkan pasien dengan kasus gawat darurat yang mendapat waktu tanggap cepat $81,3 \%$ dan lambat $18,8 \%$, pasien dengan kasus darurat tidak gawat yang mendapat waktu tanggap cepat $71,9 \%$ dan lambat $28,1 \%$, pasien dengan kasus tidak gawat tidak darurat yang mendapat waktu tanggap cepat $28,6 \%$ dan lambat $71,4 \%$. Penelitian ini sejalan dengan penelitian yang peneliti lakukan.

Sedangkan penelitian yang dilakukan oleh Apriani \& Febriani (2017) tentang hubungan kegawatdaruratan dengan waktu tanggap pada pasien jantung koroner, didapatkan bahwa dari 30 responden sebagian besar responden dengan kegawatdaruratan prioritas II sebanyak 22 orang (73,3\%). Waktu tanggap dalampenelitian ini sebagian besar pasien mendapatkan waktu tanggap yang tepat ( $\leq 5$ menit) sebanyak 23 orang (76,7\%). Penelitian ini sejalan dengan penelitian yang peneliti lakukan. 
Menurut asusmsi peneliti pasien dengan gawat darurat (P1) harus mendapatkan penanganan yang cepat dan merupakan prioritas utama yang harus di tangani, pasien dengan darurat tidak gawat merupakan prioritas ke 2 yang harus ditangani setelah prioritas utama dan prioritas terakhir yang harus ditangani yaitu pasien dengan tidak gawat tidak darurat. Tetapi pada prinsip umum yang telah ditetapkan oleh Kepmenkes (2009) bahwa penanganan yang dilakukan di IGD paling lama harus ditangani yaitu 5 menit baik pasien dengan gawat darurat, darurat tidak gawat, maupun pasien dengan tidak gawat tidak darurat. Dalam penelitian ini ada ditemukan pasien dengan ATS 3 ada $15,4 \%$ dan ATS $45,1 \%$ yang mendapatkan respon time yang tidak sesuai standar. Hal ini dikarenakan pasien yang ditemukan pada saat penelitian dengan ATS 3 dan 4 merupakan pasien yang mengalami diagnosis penyakit yang mengarah ke tanda gejala pasien Covid-19 sehingga perawat harus melakukan pengkajan skrining Covid-19 dengan detail terhadap pasien tersebut, waktu yang lama juga dapat disebabkan karena pasien atau keluarga pasien sering tidak jujur mengenai keluhan yang dialami pasien.

\section{KESIMPULAN}

Berdasarkan hasil penelitian didapatkan dari 87 responden sebagian besar responden berumur 31-50 tahun sebanyak 30 orang $(34,5 \%)$, berjenis kelamin laki-laki sebanyak 50 orang $(57,5 \%)$, dengan diagnosa medical sebanyak 69 orang $(79,3 \%)$, responden tidak pasien rujukan sebanyak 77 orang $(88,5 \%)$, dengan level kegawatan mayoritas ATS 3 dan ATS 4 sebanyak 39 orang $(44,8 \%)$ dan respon time pasien pada masa pandemi Covid-19 yang sesuai standar sebanyak 79 orang $(90,8 \%)$.

Gambaran respon time pasien berdasarkan umur dari 87 responden ada 30 responden berumur 31-50 tahun terdapat $0(0 \%)$ dengan respon time yang tidak sesuai standar, sedangkan 29 responden berumur $>50$ tahun terdapat 4 orang $(13,8 \%)$ dengan respon time yang tidak sesuai standar, berdasarkan jenis kelamin ada 50 responden berjenis kelamin laki-laki terdapat 4 orang $(8 \%)$ dengan respon time yang tidak sesuai standar, berdasarkan diagnosa ada 69 responden dengan diagnosa medical terdapat 2 orang $(2,9 \%)$ dengan respon time yang tidak sesuai standar, berdasarkan rujukan ada 77 responden yang tidak pasien rujukan terdapat 6 orang $(7,8 \%)$ dengan respon time yang tidak sesuai standar, berdasarkan level kegawatan ada 39 responden dengan ATS 3 terdapat 6 orang $(15,4 \%)$ dengan respon time yang tidak sesuai standar, sedangkan 39 responden dengan ATS 4 terdapat 2 orang $(5,1 \%)$ dengan respon time yang tidak sesuai standar.

\section{SARAN}

Bagi Ilmu Keperawatan semoga hasil penelitian ini dapat dijadikan referensi bagi mahasiswa untuk memberikan wawasan mengenai respon time pasien pada masa pandemi Covid-19 di Instalasi Gawat Darurat.

Bagi Instalasi Gawat Darurat (IGD) RSUD Arifin Achmad dengan hasil 2 menit 35 detik untuk Respon Time paling cepat dan 5 menit 8 detik untuk respon time paling lama diharapkan untuk menambahkan SDM, sarana dan prasarana penunjang yang belum ada atau kurang agar terlaksana penanganan gawat darurat yang lebih baik dan memuaskan 
Bagi tenaga kesehatan gawat darurat supaya tetap mempertahankan respon time $<5$ menit dan lebih ditingkatkan lagi dari pencapaian waktu hasil penelitian yang diperoleh saat ini, dimana untuk mewujudkan pelayanan yang memuaskan.

Untuk peneliti selanjutnya dapat mengembangkan faktor-faktor yang lain tentang peran atau pengetahuan perawat dalam ketepatan respon time pasien pada masa pandemi Covid-19 dalam penanganan kasus gawat darurat dengan menggunakan desain penelitian yang berbeda.

\section{DAFTAR PUSTAKA}

Apriani \& Febriani, S. (2017). Hubungan kegawatdaruratan dengan waktu tanggap pada pasien jantung koroner. Jurnal Kesehatan Vol. VIII No. 3, November 2017. Hal: 471477

Handayani, A.R. (2017). Hubungan waktu tanggap (respon time) perawat dengan ketepatan penanganan trauma di IGD RSUD Ulin Banjarmasin. Universitas Muhammadiyah Banjarmasin

Jaya, A. (2017). Hubungan respon time dengan kepuasan pasien di IGD RS Tingkat IV Madiun. STIKes Bhakti Husada Mulia Madiun

Keputusan Menteri Kesehatan Republik Indonesia. 2009 No. 856. (2009). Standar Instalasi Gawat Darurat (IGD) Rumah Sakit. Jakarta

Keputusan Menteri Kesehatan Republik Indonesia. (2011). Pedoman standar pelayanan Instalasi Gawat Darurat. Jakarta: Kementerian Kesehatan RI.
Mahyawati.(2015). Hubungan kegawatdaruratan pasien dengan waktu tanggap perawat di IGD RS PKU Muhammadiyah Yogyakarta. Sekolah tinggi ilmu kesehatan 'Aisyiyah Yogyakarta

Mardalena. (2016a). Asuhan keperawatan gawat darurat. Jogyakarta: Pustaka Mulia

Mufidah, L. (2018). Hubungan respon time perawat dengan complaint handling (penanganan keluhan) dalam pelayanan keperawatan di ruang Dahlia RSUD Jombang. Sekolah tinggi ilmu kesehatan Insan endekia Medika Jombang

Sabriyati, W.O.N.I., Islam, A.A., dan Gaus, S. (2012). Faktor-Faktor Yang Berhubungan Dengan Ketepatan Waktu Tanggap Penanganan Kasus Pada Response Time I Di Instalasi Gawat Darurat Bedah Dan NonBedah RSUP Dr. Wahidin Sudirohusodo. Universitas Hasanuddin. Makasar.

Surtiningsih, D. (2016). Penerapan respon time perawat dalam pelaksanaan penentuan prioritas penanganan kegawatdaruratan pada pasien kecelakaan. Vol. 6 No.2, Juni 2016

Sutawijaya. (2009). Asuhan keperawatan gawat darurat. Yogyakarta: Aulia Publishing.

Triyono, A. (2020). Hubungan response time dan komunikasi dengan kepuasan keluarga pasien di Instalasi Gawat Darurat (IGD) Rumah Sakit Ortopedi Prof. Dr. R. Soeharso Surakarta. STIKes Kusuma Husada Surakarta

WorldoMeters. (2020). Data kasus corona virus disease (Covid-19). Available from https://www.worldometers.info/coro navirus/ 